\title{
ANALOGI MODEL OSILATOR HARMONIK LOGARITMIK PENDULUM TORSI DENGAN FLUKTUASI NILAI TUKAR RUPIAH TERHADAP US DOLLAR
}

\author{
Nani Yuningsih ${ }^{1, \mathrm{a})}$, Kunlestiowati Hadiningrum ${ }^{1, \mathrm{~b})}$, Sardjito $^{1, \mathrm{c})}$ \\ ${ }^{1}$ Politeknik Negeri Bandung, Jl. Terusan Gegerkalong Hilir, Ds. Ciwaruga, Kotak Pos 1234, Bandung \\ Email: ${ }^{\text {a) }}$ nani.yuningsih@polban.ac.id, ${ }^{\text {b) }}$ kunpolban@yahoo.co.id, ${ }^{\text {c) }}$ sardjito@polban.ac.id
}

\begin{abstract}
Abstrak
Peristiwa fluktuasi nilai tukar rupiah terhadap US Dollar ada keserupaan dengan getaran paksa teredam. Untuk mengetahui adanya kemiripan fluktuasi nilai tukar rupiah terhadap US Dollar beserta faktorfaktor peubahnya dengan getaran paksa teredam, dilakukan uji model getaran paksa teredam menggunakan perangkat pendulum torsi. Untuk getaran paksa teredam sumber tegangan yang digunakan 8-8,4 V dan dengan nilai tukar rupiah terhadap US Dollar pada perioda tahun 2013 sampai 2017. Hasil analisis menunjukkan adanya kemiripan antara simpangan getaran paksa teredam dengan dinamika nilai tukar rupiah terhadap US dollar. Efek redaman pada getaran dianalogikan dengan kebijakan pemerintah untuk menstabilkan nilai tukar rupiah dan gaya paksa dianalogikan sebagai gangguan faktor eksternal. Hasil perhitungan melalui regresi sederhana dan SPSS diketahui koefisien pergerakan nilai tukar dan ampiltudo getaran mempunyai arah yang sama, yaitu arah positif. Dari uji korelasi melalui analisis deskriptif dan analisis inferensial diperoleh hubungan (korelasi) dengan kekuatan Sedang antara nilai tukar rupiah dengan simpangan getaran paksa teredam, dengan koefisien korelasi sebesar 0.595. Hal ini menunjukkan bahwa apabila nilai tukar naik (rupiah melemah), maka simpangan akan meningkat secara signifikan, sebaliknya jika nilai tukar menurun (rupiah menguat) maka simpangan akan menurun secara signifikan.
\end{abstract}

Kata-kata kunci: pendulum torsi, getaran paksa teredam, nilai tukar rupiah, uji korelasi.

\begin{abstract}
There are similarities between the Rupiah rate exchange against the US Dollar and forced damped vibration. To identify those similarities along with the variables of its effect with forced damped vibration, a forced damped vibration model is tested using a pendulum torque device. For forced damped vibration the voltage source used is $8-8.4 \mathrm{~V}$ and with the Rupiah exchange rate against the US Dollar from 2013 to 2017. The results of the analysis show that there are similarities between forced damped vibration and the dynamics of the Rupiah exchange rate against the US Dollar. The effect of attenuation on vibration is analogous to the government policy to stabilize the Rupiah exchange rate, and the forced force is analogous to the external factor disruption. The results of calculations through a simple regression and SPSS note that the exchange rate movement coefficient and vibration amplitude have the same direction, namely the positive direction. From the correlation test through descriptive analysis and inferential analysis obtained the relationship (correlation) with the medium strength between the Rupiah exchange rate with the forced damped vibration deviation, with a correlation coefficient of 0.595 . This shows that if the exchange rate rises (the Rupiah weakens), then the deviation
\end{abstract}


will increase significantly, on the contrary, if the exchange rate decreases (the Rupiah strengthens) then the deviation will decrease significantly.

Keywords: pendulum torque, forced damped vibration, Rupiah exchange rate, correlation test

\section{PENDAHULUAN}

Beberapa peristiwa ekonomi menunjukkan keserupaan (paralel) dengan peristiwa dalam alam, khususnya fisika. Peristiwa fluktuasi nilai tukar rupiah terhadap US Dollar ada keserupaan dengan getaran paksa teredam. Untuk mengetahui adanya kemiripan fluktuasi nilai tukar rupiah terhadap US Dollar dengan getaran paksa teredam, dilakukan uji model getaran paksa teredam menggunakan perangkat pendulum torsi. Pendulum torsi adalah suatu alat yang dapat digunakan untuk mengamati prilaku getaran, baik getaran bebas, getaran teredam, maupun getaran paksa. Getaran dapat berupa getaran translasi maupun rotasi. Getaran yang terjadi dalam arah rotasi sering disebut sebagai getaran torsional. Pada dasarnya karakteristik getaran torsional mirip dengan getaran translasi. Karena kemiripan antara ke dua jenis getaran tersebut, maka teori analisa yang di bahas dalam getaran translasi berlaku pula pada getaran torsional pada alat pendulum torsi.

Getaran teredam pada pendulum torsi terjadi jika pada pendulum diberikan medan magnet yang menghasilkan rem arus Eddy, yang mengakibatkan munculnya torsi peredam. Pendulum torsi akan mengalami getaran paksa bila diberikan masukan berupa tegangan listrik yang berubah terhadap waktu[1]. Jika medan magnet dan tegangan diberikan secara bersamaan, maka akan terjadi getaran paksa teredam.

Karakteristik getaran torsional mirip dengan getaran translasi, dengan mengkonversikan sudut putar ke simpangan, maka persamaan yang berlaku pada getaran torsional merupakan analogi dari getaran linier[2].

Getaran rotasional teredam terjadi bila sistem getaran bebas dipengaruhi juga oleh gaya peredam (gaya gesekan, hambatan) yang umumnya bergantung pada kecepatan gerak; artinya besar gaya peredam bergantung pada besar kecepatan sedang arahnya berlawanan [3].

Gaya peredam pada pendulum torsi berupa gaya magnet yang timbul dari GGL Imbas.

$$
F=i l B=\frac{s l B}{R}=-\frac{B^{2} l^{\mathrm{a}} \omega}{2 R}
$$

Pada osilator torsional pendulum torsi untuk getaran teredam berlaku persamaan: [4]

$$
\frac{d^{2} \theta}{d t^{2}}+\frac{B^{2} t^{4}}{4 R I} \frac{d \theta}{d t}+\frac{k}{I} \theta=0
$$

Dimana $\mathrm{I}=$ momen inersia, $\mathrm{k}=$ konstanta pegas, $\mathrm{B}=$ medan magnet, $\mathrm{I}=$ arus pusar, $\mathrm{R}=$ resistansi konduktor, $1=$ panjang kumparan, dan $\theta=$ sudut putar. Untuk redaman kecil yaitu jika

$$
\frac{B^{2} l^{4}}{8 R I}<\frac{k}{I}
$$

maka posisi sudut setiap saat dapat dituliskan sebagai berikut

$$
\theta=\theta_{0} e^{-\frac{B^{\mathrm{z}} \mathrm{l}^{4}}{\mathrm{gRI}}} e^{ \pm \omega_{r} t}
$$

Pada Getaran paksa karena adanya gaya atau torsi luar yang bekerja pada suatu sistem sehingga sistem tersebut bergetar. Gaya atau torsi yang bekerja pada pendulum torsi diatur oleh tegangan pengendali dari pasok daya. Gaya luar ini umumnya bersifat periodik berbentuk

$$
F=F_{o} \cos (2 \pi f t)
$$


Dari persamaan gaya dan gerak akan diperoleh persamaan diferensial orde dua tidak homogen, yang mempunyai bentuk

$$
\frac{d^{2} \theta}{d t^{2}}+\frac{k}{I} \theta=\frac{\tau_{0}}{I} \cos (2 \pi f t)
$$

Selain medan magnet, gaya gesekan udara juga dapat berlaku sebagai peredam getaran. Untuk faktor redaman berupa gaya gesekan udara, telah dilakukan analisis menggunakan perangkat alat momen inersia dengan menggunakan batang dan batang berbeban, dimana amplitude osilasi yang semakin lama semakin berkurang dan pada akhirnya osilasi akan berhenti. Waktu yang diperlukan untuk bergetar batang berbeban memerlukan waktu lebih lama dibanding waktu yang diperlukan untuk bergetar batang tanpa beban untuk jumlah getaran yang sama [5].

Getaran yang terjadi dan fluktuasi nilai tukar rupiah beberapa tahun dianalisis melalui regresi sederhana dan program SPSS. Hasil analisis menunjukkan adanya kemiripan antara getaran paksa teredam dengan dinamika nilai tukar rupiah terhadapUS Dollar. Apabila dikaitkan dengan kondisi ekonomi Indonesia, terdapat kemiripan antara getaran dengan fluktuasi nilai tukar rupiah. Dimana efek redaman dapat dianalogikan dengan upaya (kebijakan) pemerintah untuk menstabilkan nilai tukar seperti Intervensi BI, pinjaman luar negeri, perubahan suku bunga, dan lain lain [6].

\section{METODE PENELITIAN}

Metode yang digunakan dalam penelitian ini adalah uji korelasi dengan metode analisis deskriptif dan analisis inferensial. Instrumen penelitian terdiri dari perangkat alat pendulum torsi. Jenis getaran yang diamati getaran paksa teredam, pada harga tegangan antara 8 sampai 8,4 volt dan arus listrik 0,3 A.

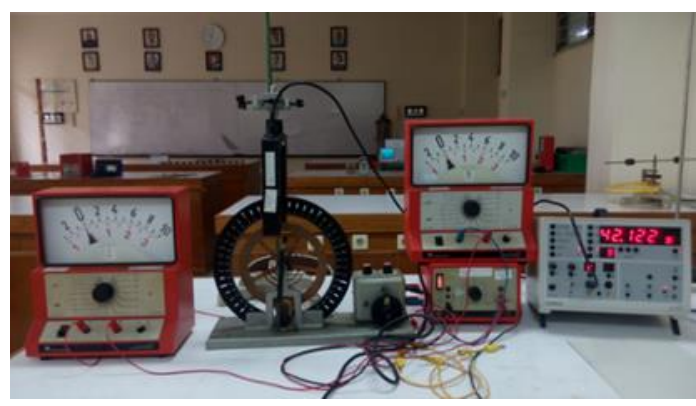

GAMBAR 1. Perangkat alat pendulum torsi

Untuk analisis fenomena ekonomi, jenis data yang digunakan adalah data sekunder. Data sekunder ini bersumber pada Bank Indonesia (BI) dan Statistik Ekonomi Keuangan Indonesia (SEKI) dan beberapa pustaka lainnya. Dalam penelitian digunakan nilai tukar rupiah terhadap US dollar, diukur dalam satuan rupiah (IDR/USD) 5 tahun terakhir, yaitu tahun 2013 sampai 2017.

Getaran yang terjadi dianalisis dengan berbantuan komputer selanjutnya dilakukan pencocokan (matching) dengan dinamika nilai tukar rupiah terhadap valuta asing untuk beberapa periode waktu, ketika terjadi fluktuasi. Kedua data tersebut dibandingkan/dicocokkan menggunakan uji korelasi.

\section{HASIL DAN PEMBAHASAN}

Untuk mengetahui adanya analogi dan kemiripan model osilator harmonik logaritmik dengan fluktuasi nilai tukar rupiah terhadap US Dollar, telah dilakukan uji regresi sederhana pergerakan nilai tukar dan getaran paksa teredam. Setelah diperoleh korelasi antara nilai tukar dengan waktu pada pergerakan nilai tukar dan korelasi simpangan getaran paksa teredam dengan waktu, kemudian dilakukan uji korelasi antara nilai tukar rupiah terhadap US Dollar pada periode tahun 2013-2017 dengan simpangan getaran paksa teredam pada tegangan 8-8,4 Volt. 


\section{Pergerakan Nilai Tukar}

Untuk mengetahui arah pergerakan nilai tukar rupiah terhadap Dollar Amerika maka dilakukan perhitungan dengan menggunakan regresi sederhana, dari nilai koefisiennya dapat diketahui arah pergerakan nilai tukar. GAMBAR 2 menunjukkan hasil perhitungan regresi sederhana yang disajikan dalam grafik.

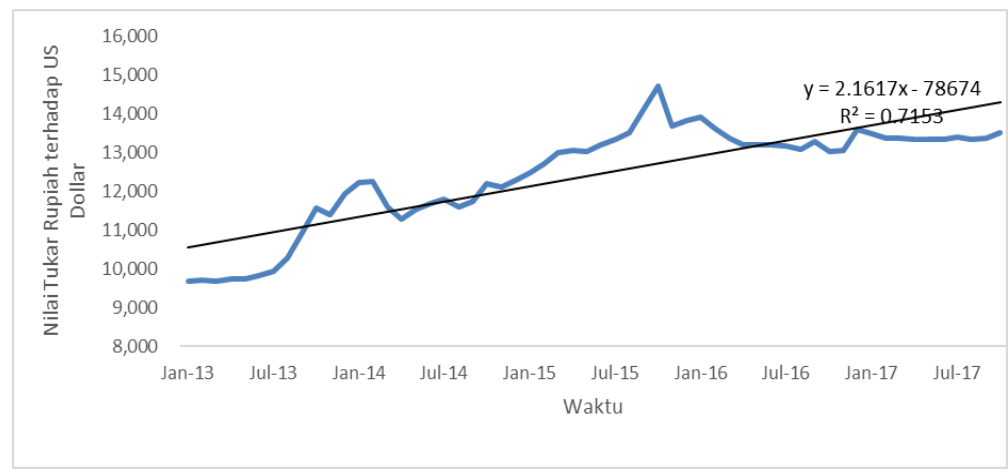

GAMBAR 2. Grafik Pergerakan Nilai Tukar

Berdasarkan grafik diatas, diperoleh persamaan regresi sederhana yaitu sebagai berikut:

$$
\text { Nilaitukar }=-78674+2.1617 \text { Periode }
$$

Persamaan (5) dapat diartikan sebagai berikut:

$\mathrm{a}=-78674$; artinya jika periode waktu tidak ada atau bernilai nol (0), maka nilai tukar akan bernilai -78674 satuan.

$\mathrm{b}_{1}=2.1617$; artinya semakin lama periode waktu, maka akan mengakibatkan pergerakan nilai tukar yang semakin baik (positif), dengan besaran peningkat 2.1617satuan.

\section{Analisis Koefisien Determinasi}

Berdasarkan GAMBAR 2, diketahui bahwa periode waktu memberikan pengaruh positif terhadap pergerakan nilai tukar sebesar 0,7153 atau $71,53 \%$, sedangkan sisanya sebesar $28,47 \%$ merupakan pengaruh dari faktor lain yang belum diteliti.

\section{Uji Parsial (Uji t)}

$\mathrm{H}_{0}$ : periode waktu tidak berpengaruh positif dan signifikan terhadap pergerakan nilai tukar;

$\mathrm{H}_{1}$ : periode waktu berpengaruh positif dan signifikan terhadap pergerakan nilai tukar.

Berdasarkan perhitungan dengan menggunakan SPSS, maka diperoleh hasil sebagai berikut:

TABEL 1. Hasil uji parsial (Uji t) dengan nilai tukar sebagai variabel terikat

\begin{tabular}{ccrc}
\hline & Model & t & Sig. \\
\hline \multirow{2}{*}{1} & $($ Constan $)$ & 33.011 & .000 \\
& Periode & 1.181 & .242 \\
\hline
\end{tabular}

Probability (p-value) sebesar 0,242.Jika dibandingkan dengan alpha 5\% $(0,05)$, maka nilai ini lebih besar dari 0,05 atau 0,242>0,05, yang menunjukkan bahwa $\mathrm{H}_{0}$ diterima, artinya periode waktu tidak berpengaruh signifikan, namun positif terhadap pergerakan nilai tukar. 


\section{Getaran Paksa Teredam}

Untuk mengetahui arah pergerakan getaran paksa teredam dengan tegangan antara 8-8,4 V dan arus listrik 0,3 A maka dilakukan perhitungan dengan menggunakan regresi sederhana, dari nilai koefisiennya dapat diketahui arah pergerakan amplitudonya. GAMBAR 3 menunjukkan hasil perhitungan regresi sederhana yang disajikan dalam grafik.

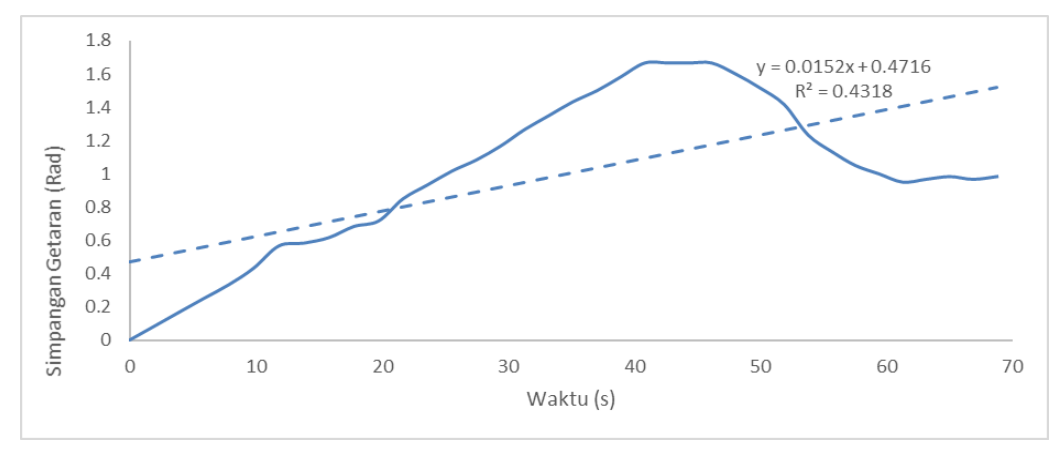

GAMBAR 3. Pergerakan gataran paksa teredam

Berdasarkan grafik pada GAMBAR 3, diperoleh persamaan regresi sederhana yaitu sebagai berikut:

$$
\text { Simpangan }=0.4716+0.015 \text { waktu }
$$

Persamaan (7) di atas dapat diartikan sebagai berikut:

$\mathrm{a}=0.4716$; artinya jika periode waktu tidak ada atau bernilai nol (0), maka Simpangan akan bernilai 0.4716 satuan.

$\mathrm{b}_{1}=0.0152$; artinya semakin lama periode waktu, maka akan mengakibatkan pergerakan simpangan/resonansi yang semakin bagus (positif), dengan besaran peningkat 0.0152 satuan.

\section{Analisis Koefisien Determinasi}

Berdasarkan grafik pada GAMBAR 3 diketahui bahwa periode waktu memberikan pengaruh positif terhadap pergerakan amplitudo pada tegangan $8-8,4 \mathrm{~V}$ sebesar 0,4318 atau $43,18 \%$, sedangkan sisanya sebesar 56,82\% merupakan pengaruh dari faktor lain yang tidak diteliti.

\section{Uji parsial (Uji t)}

$\mathrm{H}_{0}$ : periode waktu tidak berpengaruh positif dan signifikan terhadap pergerakan Resonansi 8-8,4 V (simpangan);

$\mathrm{H}_{1}$ : periode waktu berpengaruh positif dan signifikan terhadap pergerakan Resonansi 8-8,4 V (simpangan).

Berdasarkan perhitungan dengan menggunakan SPSS, maka diperoleh hasil sebagai berikut:

TABEL 2. Hasil uji parsial (Uji t) dengan resonansi 8-8,4V sebagai variabel terikat

\begin{tabular}{cccc}
\hline & Model & t & Sig. \\
\hline \multirow{2}{*}{1} & $($ Constan $)$ & 3.958 & .000 \\
& Periode & 5.157 & .000 \\
\hline
\end{tabular}

Berdasarkan hasil diatas, diperoleh nilai probability (p-value) sebesar 0,000. Jika dibandingkan dengan alpha 5\% (0,05), maka nilai ini lebih kecil dari 0,05 atau $0,000<0,05$, yang menunjukkan bahwa $\mathrm{H}_{0}$ ditolak, artinya periode waktu berpengaruh positif dan signifikan terhadap getaran paksa teredam pada tegangan $8-8,4 \mathrm{~V}$, arus $0,3 \mathrm{~A}$. 


\section{Korelasi Nilai Tukar Rupiah terhadap US Dollar dengan Simpangan Getaran Paksa Teredam}

GAMBAR 4. menunjukkan grafik pergerakan nilai tukar rupiah terhadap terhadap US Dollar dan getaran paksa teredam dan terlihat ada kemiripan profil grafik. Besaran-besaran pada getaran di analogikan dengan faktor-faktor yang berpengaruh pada nilai tukar rupiah terhadap US Dollar. Hal ini menunjukkan adanya kesesuaian fluktuasi nilai tukar rupiah terhadap US Dollar dengan getaran paksa teredam.

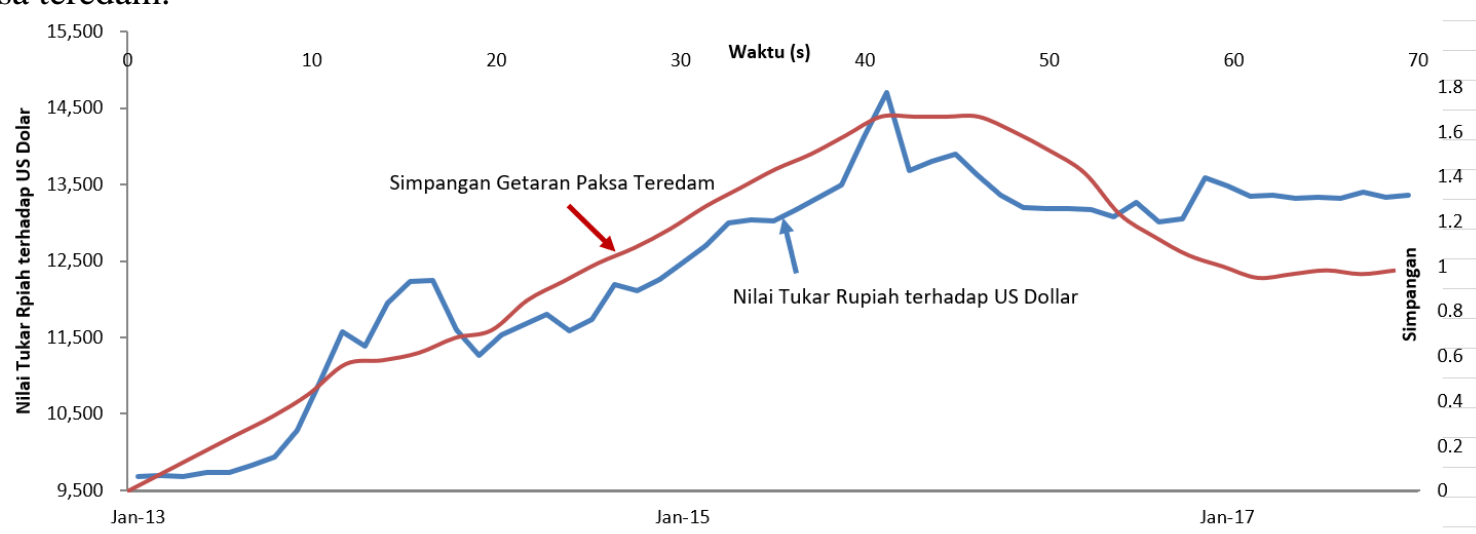

GAMBAR 4. Pergerakan gataran paksa teredam dan Pergerakan Nilai Tukar

\section{Analisis Deskriptif}

TABEL 3. Analisis deskriptif

\begin{tabular}{lccccc}
\hline \multicolumn{1}{c}{ Model } & N & Minimum & Maximum & Mean & Std. Deviation \\
\hline Nilai Tukar & 58 & 9678.00 & 14709.00 & 12423.71 & 1313.79933 \\
Simpangan & 37 & .00 & 1.67 & 1.0023 & .47852 \\
Valid N (listwise) & 37 & & & & \\
\hline
\end{tabular}

Berdasarkan hasil output SPSS diatas diperoleh bahwa Nilai tukar mempunyai nilai minimum sebesar 9678.00, nilai maksimum sebesar 14709.00, nilai mean sebesar 12423.71, dan simpangan baku sebesar 1313.79933. Juga terlihat nilai simpangan getaran pegas teredam minimum sebesar 0,00 dan maksimum 1,67, nilai mean sebesar 1,0023 dan simpangan baku 0,47852.

\section{Analisis Inferensial}

$\mathrm{H}_{0} \quad$ : Tidak terdapat hubungan (korelasi) yang signifikan antara Nilai Tukar dengan Simpangan

$\mathrm{H}_{\mathrm{a}} \quad$ : Terdapat hubungan (korelasi) yang signifikan antara Nilai Tukar dengan Simpangan

$\alpha=5 \%$

TABEL 4. Analisis hubungan antara nilai tukar dengan simpangan

\begin{tabular}{clcc}
\hline & & Nilai Tukar & Simpangan \\
\hline \multirow{2}{*}{ Nilai Tukar } & Pearson Correlation & 1 & $.595^{* *}$ \\
& Sig. (2-tailed) & \multicolumn{2}{c}{.000} \\
& N & 58 & 37 \\
\hline Simpangan & Pearson Correlation & $.595^{* *}$ & 1 \\
& Sig. (2-tailed) & .000 & 37 \\
\hline
\end{tabular}


TABEL5. Hasil Uji Korelasi antara Nilai Tukar Rupiah dengan Simpangan Getaran Paksa Teredam

\begin{tabular}{cccccc}
\hline Hubungan & $\begin{array}{c}\text { Koefisien Korelasi } \\
\text { Pearson }\end{array}$ & $\begin{array}{c}\text { Kekuatan hubungan } \\
\text { (korelasi) }\end{array}$ & t hitung & t tabel & Kesimpulan \\
\hline $\begin{array}{c}\text { Nilai Tukar } \\
-\end{array}$ & 0.595 & Sedang & 5.54 & 2.00 & $\begin{array}{c}\text { Terdapat hubungan } \\
\text { yang Signifikan }\end{array}$ \\
\hline
\end{tabular}

Dari hasil perhitungan output SPSS di atas, diperoleh koefisien korelasi Pearson sebesar 0,595 Berdasarkan pedoman interpretasi Guildford, korelasi 0,595 termasuk pada kategori hubungan (korelasi) yang Sedang.

Dikarenakan t hitung (5.54) > t tabel $(2,00)$, maka $\mathrm{H}_{0}$ ditolak dan $\mathrm{H}_{\mathrm{a}}$ diterima, artinya terdapat hubungan (korelasi) yang signifikan antara Nilai Tukar dengan Simpangan dengan kekuatan hubungan (korelasi) sedang. Maka dapat disimpulkan bahwa terdapat hubungan (korelasi) dengan kekuatan sedang antara Nilai Tukar dengan Simpangan. Artinya apabila Nilai Tukar selanjutnya lebih berkembang dan ditingkatkan lagi, maka Simpangan akan meningkat secara signifikan, begitu juga sebaliknya jika nilai tukar menurun maka Simpangan akan menurun secara signifikan. Atau sebaliknya jika Simpangan naik maka nilai tukar juga naik dengan sifnifikan atau sebaliknya.

\section{PENUTUP}

Berdasarkan uji regresi sederhana pergerakan nilai tukar rupiah terhadap US Dollar lima tahun terakhir yaitu dari tahun 2013 sampai dengan 2017 dan getaran paksa teredam melalui perangkat pendulum torsi pada saat $8-8,4 \mathrm{~V}$ dan arus listrik $0,3 \mathrm{~A}$ dapat diketahui bahwa keduanya memiliki pergerakan yang sama yaitu perubahan ke arah positif. 1.Terdapat hubungan (korelasi) yang signifikan antara Nilai Tukar dengan Simpangan dan mempunyai hubungan (korelasi) dengan kekuatan Sedang.

\section{UCAPAN TERIMAKASIH}

Ucapan terimakasih disampaikan kepada Direktorat Riset dan Pengabdian kepada Masyarakat (DRPM), Kemenristekdikti melalui Unit Penelitian dan Pengabdian kepada Masyarakat (UPPM) Politeknik Negeri Bandung yang telah mendanai penelitian skema Penelitian Strategis Nasional tahun ke dua tahun anggaran 2018.

\section{REFERENSI}

[1] Joni Dewanto," Kajian Teoritik Sistem Peredam Getaran Satu Derajat Kebebasan,” Jurnal Teknik Mesin, Vol. 1, No. 2, pp. 156 - 162.

[2] Halliday, Resnick, Walker, "Oscillations"in Fundamental of Physics, 6th ed. New Delhi, India: Wiley, 2006, pp 346-362.

[3] A. Susilo, M. Yunianto and V. I. Variani, "Simulasi Gerak Harmonik Sederhana dan Osilasi," Indonesian Journal of Applied Physics, vol. 2, no. 2, p. 124, 2012.

[4] N. Yuningsih et al, "Model Getaran Paksa Teredam pada Pendulum Torsi yang Diaplikasikan pada Dinamika Nilai Tukar Rupiah terhadap Valuta Asing," presented at Seminar Nasional Fisika dan Aplikasinya, Jatinangor, Ind., 2017.

[5] N. Yuningsih et al, "Analisis Getaran Rotasional Teredam Sistem Batang Homogen dan Pegas Torsional untuk Dikembangkan sebagai Model Fluktuasi Ekonomi," in Prosiding Seminar Nasional Fisika 2017, Jakarta, 2017, pp 23-30, DOI:doi.org/10.21009/03.SNF2017.02.CIP.04. 
[6] K. Hadiningrum, N. Yuningsih and Sardjito, "Application of Physics Phenomenon Model Towards Economic Symptoms in Indonesia (Spring Oscillation Model and Rupiah Rate Exchange)," Economics World, vol. 6, no. 2, p. 133, 2018. 